\title{
Political Economy of Islamic Banking in Indonesia
}

\author{
Ahmad Dahlan \\ Lecturer \\ Faculty of Economics and Islamic Business \\ IAIN Purwokerto, Indonesia
}

\begin{abstract}
There is a unique with Indonesia, as a Muslim majority country, but first Islamic bank in Indonesia established in 1992. Whereas politically, Indonesia is a member of OIC (Organization of Islamic Conference), an institution directly involved in the establishment of Islamic Development Bank (IDB). The establishment of Islamic bank in Indonesia in 1992 was a process of intersection and influence of political infrastructure (ICMI, MUI, LSAF, etc.) to the political superstructure of policies that contained Islamic symbolism in banking. Whereas in the period before 1992, politic (the state) still contradicted o the Islam symbolization. From this historical background, then this research began as part of the political economy that study the Islamic banking in Indonesia. This research is a library research, with content analysis method, and historical approach. The results show that in the national aspect, the movement of political infrastructure in the field of Islamic economy (such as banking) is more effective in the Islamicdevelopment of the political superstructure policies. Even the effect of policies Islamization in the Islamic banking field extends to other fields such as politics, law, academic, and social. While in the regionalglobal aspect, the presence of Islamic bank in Indonesia has removed the anomaly of Indonesia as a Muslim majority country (sociologist), member of OIC and founder of IDB (political) but does not have Islamic bank. But since 1992, Indonesia has been affirmative towards the development of Islamic financial institutions (economical).
\end{abstract}

Keywords: Islamic political infrastructure, policy of political superstructure, Islamic banking.

\section{Introduction}

Indonesia is losing rapidly with Malaysia which established Bank Islam Malaysia Berhad (BIMB) in 1983, and in the Philippines stood Al-Amanah Islamic Investment Bank (Philippines) in 1990. Compared to other countries in the Middle East, Indonesia lags far behind Dubai Islamic Bank UAE (1975), Faisal Islamic Bank of Sudan (1977), Bahrain Islamic Bank (1979), and others. Related to the Muslim population and political aspects in responding to the Islamic bank development, there are several studies. Engzell (Uppsala University, Sweden, 2008:3) found the growth of Islamic finance at world level increased by about $15 \%$ to 250 billion pounds. But it's institution is difficulty to integrate and to compete into the Western economy.

However, there are Islamic banks that can develop in non-Muslim countries like in the UK. Some of the factors that support such success are political and sociological factors. The Financial Services Authority (FSA) UK is politically very encouraging towards the development of Islamic bank. While the sociological aspects are reflected in the presence of Muslim populations who are very passionate in reporting of Islam (Engzell, 2008: 3)

Belouafi and Chachi (2014: 38), explains that Britain is a very active country for the development of Islamic finance, from economic or political aspects. The minority Muslim population in the UK but able to respond the Islamic bank development further reinforced the uniqueness of the Islamic bank development in Indonesia which was present in 1992. It's not reflect the sociological realities (Muslim majority), and political reality (OIC members). 1992 was a very long span of time from 1973 when the IDB was founded. So in this paper will be traced on the social, economic, and political background in the establishment of Islamic bank in Indonesia in the 1990s with the approach of political economy, the study of the interrelation of political power (political superstructure) with the Muslims interests (political infrastructure). The study of the interrelation of the political superstructure in Indonesia in the 1990s with the Islamic political infrastructure has been done by many experts, such as M. Syafi'i Anwar (1995), Bachtiar Effendy (1998), Kemaruzzaman Bustaman Ahmad (2004), Richard Robison (1990, 1996), Robert W. Hefner (2001), Vedi R Hadiz (2011), and others. 
However, these studies focus more on the purely Islamic socio-political studies, have not studied much about Islamic bank or Islamic economics. According to Perwaatmadja (2016) and Antonio (2016), from the establishment process to the opening of a Islamic bank (with the principle of profit sharing) in the 1990s, there was an excitement in the political superstructure to make it happen. There is hardly any resistance or debate that leads to the disruption of the Islamic bank establishment. Whereas in the real plains in the community (Islamic political infrastructure), there is still disagreement about bank interest as an economic activity that is contradictory or not to Islamic system. To reinforce that the political economy research of Islamic banking in a country as a very urgent. I found that similar research; Clement W. Henry (2015) in research in Indonesia, Mutiara Dwi Sari, et al. (2016), conducting research in Indonesia and Malaysia, and Okeke V.O.S and Ojukwu Uche Grace (2012) conducting research in Nigeria. Some of these studies show that the development of Islamic bank in many countries has become part of academic research.

\section{Theory Framework}

\section{Coalition of Political and Economic Interest Theory}

I includes "Coalition of Political And Economic Interest Theory" as the basic theory of political economy which is referred to the Mallarangeng (2002). According to the Coalition of Political And Economic Interest Theory, policy changes require broad coalition support from various economic groups. Therefore change is only possible when a winning group of coalition is stronger to compel the policy makers to adopt a specific policy. The advantage of this theory lies in its basic assumption that the policy chang reflects the greater change in the society. The problem of this theory oversimplifies the complicated problem in the question of the economic group interests.

\section{Integration of Religion, Economics, and Politics Theory}

Integration of Religion, Economics, and Politics Theory, I develop from several theories; Firstly, Mallarangeng (2002) explains the Coalition of Political and Economic Interest Theory (as described). Secondly, Ayubi (1991) which explains in political necessity needs to be mobilized by a reform towards the realization of 3D (al-din, aldunyâ, al-daulah). Third, Caporaso and Levine (2008:7) which explains that political economy as an interrelation of various aspects of economic and political institutions in an economic policy. Fourthly, Yustika (2009:2) which explains the political economy believes that the power structure will affect the economic achievement, otherwise the pure economic approach considers the power structure in market is given. Fifth, Effendy (2009:214) which explains that the unfavorable relationship between Islam and the state so as to impact the elimination of Islamic political role to participate fully in the development of Indonesian politics, especially in 1970 to 1980s. Then the convergence interrelation between Islamic politic and state found in 1992an when both accommodate each other's interests.Of the five theories mentioned above, then construct the "Integration of Religion, Economics, and Politics Theory". The theoretical plot can be seen in the following schematic drawings:

Chart 1

Framework of the Integration of Religion, Economics, and Politics Theory Islamic Political Economy

Notes:

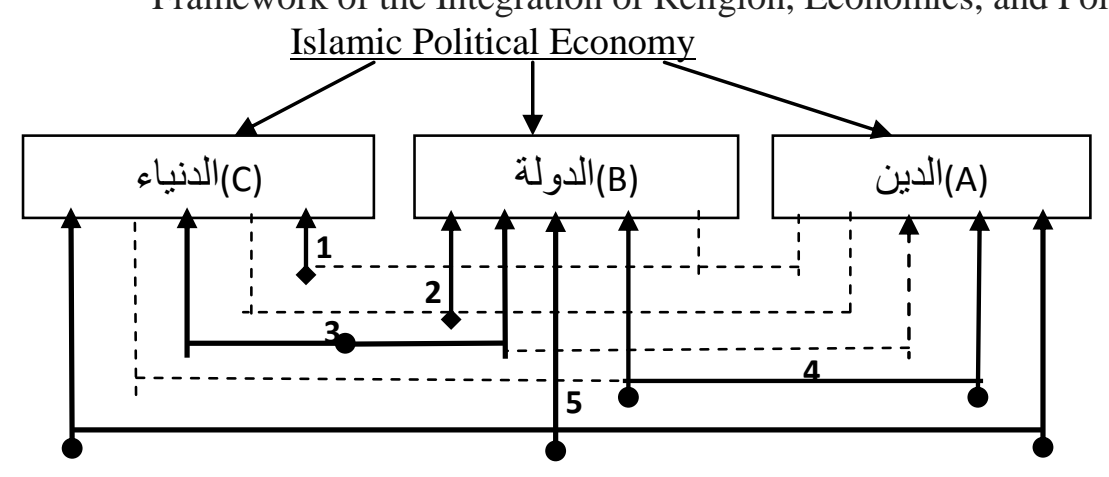

1. Economic Studies, 2. Political Studies, 3. Political Economy Studies

4. Political Studies of Islam (pure), 5. Studies of Islamic political economy

The study of political economics refers to the "criticism" of the problem of pure economic studies (C) nonbinding with power (B) (line number 1), and criticism of political studies that only examine aspects of power and policy (line number 2) Later, the study of political economy developed as a field of study that discusses the 
economic and power structure interrelation(Caporaso). Or views on economics that are not given in forming power structure (market), but there is another element that is politics (Yustika).

However, they only concern "integration of aspects $\mathrm{B}$ and $\mathrm{C}$ ", both of which are not binding on ideological/religious elements or aspects (lines B and C are cut off to al-dîn (A).

While the more dominant Islamic political studies only extend to the social-political policy aspect, rarely extending to the economic policy aspect (line 4). From the disconnection of study relationships in 3 disciplines of science (religion, politics, and economics), I construct the Integration of Religion, Economics, and Politics Theory. It is as part of the study of Islamicpolitical economy started from the existence of three big disciplines of science and ideology namely; religion (al-dîn), economic (al-dunyâ), and politics (al-daulah)have integrative. The interrelation between al-daulah and al-din (personified with the society/Islamic thinkers/Islamic political infrastructure) in "integrative" conditions, does not marginalize each other, which can give rise to the al-dunyâ policies includingthe principles of al-dîn (like Islamic bank). Then this phenomenon is called the study of Islamic Political Economy (line number 5 in the picture).

\section{Research Methods}

\section{Type of Research}

This research focuses on library research with the theme of Islamic banking in Indonesia. The focus of the study is the things related to political infrastructure in forming the interrelation with the political structure so that the birth of Islamic banking policy in Indonesia in 1992.

\section{Data Collection Method and Data Analysis}

Data collection methods used are documentation and interview. While data analysis is qualitative with content analysis method (Sujono and Abdurrahman, 1998:13). The workings of content analysis can be seen in the following figure:

\section{Figure 2}

Content Analysis Framework

Political Economy of Islamic Banking in Indonesia 1992

\begin{tabular}{|c|c|}
\hline CONTEXS REAL DATA & CONTEXS RESEARCHER DATA \\
\hline 1. THE RIIL PHENOMENON & 1. TARGET FINDINGS / RESULTS \\
\hline $\begin{array}{l}\text { The Phenomenon of Islamic } \\
\text { Banking Development in } 1992 \text { as } \\
\text { the initial Data (material) }\end{array}$ & $\begin{array}{l}\text { It can be known various historical aspects (thesis } \\
\text { approach) about the background and influence of the } \\
\text { presence of the first Islamic bank in } 1992 \text { by analyzing }\end{array}$ \\
\hline 2. MAIN DATA & by theories of political economy \\
\hline \multirow{2}{*}{$\begin{array}{l}\text { Fundamental Policy of Islamic } \\
\text { banking 1992: } \\
\text { - UU No. 7/1992 about Banking } \\
\text { - PP No. 70, } 71.72\end{array}$} & 2. DATA OF ANALISYS TOOLS \\
\hline & $\begin{array}{l}\text { - Thesis of political economy, Islamic politic, Islamic } \\
\text { banking } \\
\text { - Journals and books of political economy, Islamic } \\
\text { banking } \\
\text { - Document and interviews }\end{array}$ \\
\hline $\begin{array}{l}\text { 3. THE SYMPTOMS AND THE } \\
\text { CONFIRMING CONDITIONS }\end{array}$ & 3. INFLUENCING SYMPTOMS AND CONDITIONS \\
\hline $\begin{array}{l}\checkmark \text { New Orde } \\
\text { - Insfrastructur of Political Islam } \\
\checkmark 1 \text { Islamic Party } \\
\checkmark \text { There are classes and factions } \\
\text { within the Muslim community } \\
\text { - Economy } \\
\checkmark \text { Superior Chines } \\
\checkmark \text { Muslim inferior } \\
\text { - Social } \\
\text { There is a Muslim intellectual } \\
\text { movement about Islamic banks }\end{array}$ & $\begin{array}{l}\text { - Politic Rezim } \\
\checkmark \text { New Orde, pre 1992; Authoritarian, Repressive } \\
\checkmark \text { New Orde, 1992; acommodating } \\
\text { - Infrastructur of Political Islam } \\
\checkmark \text { Pra 1992: substansialist, marginal } \\
\checkmark \text { 1992: substansialist, religious-intellectual } \\
\text { - Economy } \\
\text { Pre 1992; muslimBourgeois } \\
\checkmark \text { Pre 1992; bourgeois-muslim minority } \\
\checkmark \text { Paska 1992; bourgeois-muslimgrowing } \\
\text { - Social } \\
\checkmark \text { Muslim intelectual growing }\end{array}$ \\
\hline & $\checkmark$ Islamic banking Issue growing \\
\hline
\end{tabular}




\section{Research Approach}

3. GEJALA DAN KONDISI YANG
MEMPENGARUHI

The approach used is a historical approach, which is to examine the background and development of the issues studied. It is used to explain how the economic, political, and social background of the establishment of the first Islamic bank, and how to develop policies that encouraged the development of Islamic banking in Indonesia in 1992.

\section{Islamic Political Infrastructure In The Establishment Of Islamic Bank In Indonesia1992}

\section{Embryo of Islamic Bank Thought before 1992}

The historical aspect, ICMI (Indonesian Muslim Scholars Association) is an important institution in order to establish Islamic bank in Indonesia in 1992. But there is an important ICMI embryo in the idea of Islamic economic system and Islamic bank namely LSAF (Institute of Religious Studies and Philosophy).

I found much research the history or political economy of Islamic banking in Indonesia but did not mention the existence of LSAF. Even though,the LSAF existence is very fundamental related to Islamic economic idea in particular and intellectual Islam in general. The LSAF is a forum for study and communication of religious, cultural, philosophical and social issues. The study involves experts, scholars and enthusiasts of these issues and communicates relevant ideas and thoughts in seminars and discussion forums and publicly publishes contemporary and actual Islamic ideas and thoughts. In the LSAF there are M. DawamRahardjo, Ahmad Syafi'iMa'arif, M. Syafi'i Anwar, and others.

According to Ma'arif (1995a: 129), the LSAF is a proof of the intellectual gait of Muslims in making breakthroughs of proud Islamic thought.

On that basis, LSAF is a proof of intellectual process that is very important in the development of Islamic economic system and Islamic bank in Indonesia. The intellectual development of the LSAF is embodied in the Journal of Ulumul Qur'an, where intellectuals, scholars, and technocrats united to pour very comprehensive and constructive Islamic ideas, including on Islamic financial systems and institutions. Such as in the Journal of Ulumul Qur'an, Vol. II, 1990 M/1411 H, specifically examines the various views of business or management ethics in Islam. There are articles of Sayyid Hussein Nasr, "Pandangan Islam Tentang Etika Kerja(The Islamic View of the Work Ethic)", Ahmad S. Adnanputra, "Nilai-nilai Islam dan Budaya Korporat (The Islamic Values and Coorporate Cultures", serta Muhammad Imaduddin Abdulrahim, "Sikap Tauhid dan Motivasi Kerja (Tauhid's Attitude and Work Motivation)".

However, during the 1998 economic crisis that catapulted the price of paper has affected the Journal Ulumul Qur'an collapse and not published more than 10 years. Then on May 10, 2012, DawamRahardjo, founder and Head Redactur, declared the JournalUlumul Qur'anis back to answer the Muslim needs in expressing the quality thinking (Kompas.com, May 10, 2012).

Rahardjo, since the 1980s has been initiated on the prohibition of usury(riba) and the idea of Islamic economic system.He is a LSAF proponent and very explicit to say that the bank interest as a riba. He is also an economic thinker who often incorporates Islamic elements or values in his articles. Some of his article in the Journal of Ulumul Qur'an (1991:50), or in the book Etika Ekonomi dan Manajemen (1990), it will be very good to his articles that incorporates the values of Islamic economic system.

The LSAF was the driving force in the first Muslim intellectual gathering organized by the Indonesian Ulama Council (Majelis Ulama Indonesia/MUI), two Islamic universities, and four NGO that initiated the idea of establishing a Muslim intellectual in 1984. To be continued in 1987 at a meeting of Muslim scholars on the campus of Djuanda University, Bogor, in the "patronage" of Alamsyah Ratu Perwiranegara, the idea of forming a bond of Muslim scholars was reinforced (see the brief history of ICMI in the next page).

The existence of LSAF is never reviewed by various articles on study the historyor political economy of Islamic bank or Islamic financial institutions in Indonesia. LSAF's disconecting in the process of Islamic economic thought or idea in Indonesia, I think the LSAF is purely the group of the intellectual (social) movement without any element or closeness to power politics.

While ICMI is the group that is very near to the politics or supra politic power so that its existence is more visible, and the ICMI institutional more massive and national. 


\section{Leading Sector of Islamic Political Infrastructure in Establishment of First Islamic Bank in 1992 a. ICMI-MUI}

ICMI stems from the idea of some students in 1987 who discussed the polarization of Islamic leadership. The discussion was responded by various scholars, especially ZA. Akhmadi (Rector of Unibraw) and A. Malik Fadjar (Rector of UMM), and several Islamic figures.

Then officially ICMI was formed at the "National Symposium of Muslim Scholars: Building the XXI Century Society" on 6-8 December 1990 in Malang (Anwar, 1995: 255, Thaba, 1996: 290, Muhammad (ed.), 1991: 5). The naming of ICMI with C (intellectual) is the idea of B.J. Habibie previously initiated by NurcholisMadjid under the name ISMI (Indonesian Muslim Scholar Association), (Rahardjo, 1996: 23).

The establishment of ICMI was responded by various outside thinkers. SaifulMujani (in Fauzi (ed.), 1995:76-77), said that Hefner (1995), an anthropologist from Boston University (USA), suspects Soeharto's support for ICMI's establishment as an opportunist strategy, because of his political stance that sees a change -a positive change about "Islamization" especially in the middle class society.

Nakamura (1993), an anthropologist from Chiba University (Japan) and Harvard University (AS), argues that the founding of ICMI is a result of the structural transparency of Indonesian society that finds the convergence of dual social and political processes, and the rise of the scholar middle class in two decades. The condition as a sign of Indonesia is moving towards a very developed Muslim nation.

From these two opinions, the presence of ICMI has created the dynamics of Indonesian Muslim society, considered positive as the rise of Indonesian Muslims, otherwise considered negative if its views are overwhelmed by prejudice and fear of Islam (Islam phobia).

Although, all opinions that disagreed the ICMI presence due to Islam phobia. Gus Dur was a Muslim who disagreed with ICMI, just in the contex of formal political Islam. He think the Islam is more appropriate as a foundation of the ethical values of modern society, because Indonesia is a multi-ethnic and multi-religious country.

Vedi R. Hadiz (2011:18-20), Professor of Asian Societies and Politics at Murdoch University, argued that tensions between rulers and political Islam were significantly "benign" after the founding of ICMI. This vehicle can provide a route to bureaucratic power for the "new Muslim middle class" that emerged during the modernization process. ICMI became an organization filled with state bureaucrats, as well as Muslim political activists who had previously criticized the state.

Importantly, indigenous businessmen such as FahmiIdris and Fadel Muhammad play an important role in ICMI. Using ICMI's mandate, they announce the need for a more balanced distribution of economic wealth, and economic power criticism of China's business conglomerate.

As Robison and Hadiz observed:

For many, the founding of ICMI signaled a new era in which Islam finally 'arrived' as a social and political force.

In euphoria, some opinions see ICMI as a possible tool for attacking people who were held responsible in the past because of Muslim emphasis, including within military circles.

According to Kara (2005:174-175) referring Rahardjo (1996:23), the establishment of ICMI is the most important milestone in the accommodative relationship between Islam and the state because in this organization met various Islamic leaders from bureaucrats and non bureaucrats.

Aritonang (1990:52) portrays idealist ICMI as a means of uniting anthropocentric to theocentric, or uniting intellectually with the spiritual.

ICMI's idealism was very precise in the 1990s. Sociologically, at this time there is an increase in religiosity, many Muslim families some schools abroad.

President Suharto is expected to participate in the heavy duty of intellectuals such as ICMI. The responsibility of scholars is not only in terms of knowledge and science, but also political interests.

President Soehar to responded concretely by accommodating the Minister of Development Cabinet VI in 19931998, which is almost 90\% Muslims, and some ministers are ICMI administrators. As Mar'ie Muhammad became Minister of Finance, Abdul Latif became Minister of Labor, TarmiziTaher became Minister of Religion. So the birth of ICMI is very natural, although the initiator is a student (Muhammad (ed.), 1991:31-32). 
For Karnaen (2016), ICMI is a strategic vehicle in releasing Islamic banking issues with the jargon of "bank without interest", as well as guarding oneself from the Islamophobio.

Evidently, ICMI was the one that encouraged the MUI National Congress to give birth to the first Islamic bank in Indonesia (BMI). Things that are difficult to do by Islamic organizations in the MUI or even outside the MUI in moving the establishment of Islamic banks in Indonesia.

The existence of ICMI as the axis of Islamic banking establishment is very smooth under the leadership of BJ. Habibie who in the 1990s served as Minister of Research and Technology, Head of BPTT (Agency for Assessment and Application of Technology), and Habibie is a person who is very trusted by Soeharto. Clement W. Henry (2015) called the first Islamic bank presence in 1992 a major role for BJ. Habibie.

\section{b. Intellectual Group}

Dwi Sari et al. (2016:179-181) explains that the thoughts and ideas of Islamic banks in Indonesia can be referred to the movement of K. H. Mas Mansur (Chairman of Muhammadiyah) in the 1930s. He was the first to think of the idea that Islamic bank should operate without a system of interest. For him, the interest of conventional banks is illegal (haram) because there is an element of extortion. His idea led to reactions and debates among scholars and socialist leaders such as Muhammad Hatta. Because according to the socialists that the interests of conventional banks are voluntary between the two parties, there is no element of extortion, coercion, and the amount required is not large.

When the Islamic Development Bank was established in Jeddah in 1975, Indonesia was involved in its founding. But the New Order's political policy continued to link the establishment of Islamic banks with Islamic state issues. Islam was developed solely for worship, the ideology of life, not in the Indonesian constitutional system. In 1982an, A.M. Saefuddin along with Amin Aziz, AbdillahThoha, AdiSasono, and M. DawamRahardjo, established the Center for Agribusiness Development (PPA). The grand design does not focus on Islamic economic projects, but the ideas of the Islamic economic movement are discussed. Amin Aziz from PPA who led the study group to discuss the idea of Islamic economic movement independently in universities, so that held "First National Conference of Islamic Economics" in Bandung, 1983.

Then an experiment on Islamic finance institutions was formed by Salman Mosque activist students, Institute of Technology Bandung by establishing Baitut-TamwilTeknosa in 1984, which was originally in the form of Teknosa Expertise Cooperative (Choiruzzad and Nugroho, 2012:959 in Utama (ed.), 2013). The presence of BMT Teknosa, then followed up by religious leaders who are members of the MUI to do deepening about the concepts of Islamic finance including the Islamic banking system (Kompas.com, Nov $26^{\text {th }}, 2008$ ).

The campaign of the Islamic economic movement and criticism the existing economic practices such as conventional banking sparked controversy in society. Prestigious magazine Tempo also describes the campaign of economic Islamization has attracted to public attention and invited responses from various community.

In 1984, the idea of Islamic bank establishing was present again; First, the regional socio-political influence of a growing Malaysian Islamic bank (BIMB) and successful. Second, referring to Hefner (2001:504) in the 1980s, emerging new modernists (young Muslim thinkers). They campaign not to conquer the country, but for educational and cultural reforms with a new (global) democratization and human rights discourse. They argue that the ultimate goal of Muslim politics, not a centralized state with a monopoly over political and cultural rights, but on Muslim civil society capable of compensating for state power, and promoting a public culture of pluralism, public participation and social justice.

Indrastomo, Ph.D from Durham University, explained that the presence of Islamic finance in Indonesia can not be separated from namely an alternative economic system based on the values and norms of Islam. This movement was aspired by the failure of the New Order that was unable to fulfill its promise, bringing social justice and equality into economy.

The Islamic economic movement in Indonesia is not merely a vocal effort to bring the "Islamic legal tradition" into the socio-economic and scope relationships as Hefner (1996) suggests. In contrast, the Islamic economic movement in Indonesia is influenced by the hope of creating a just and equitable economic system, which is more related to maqâsid sharî'a or sharî'a goals than the formalistic interpretation of Islamic jurisprudence. 
But the signs of Islamic identity have generally begun in the middle-class movement of Islamic identity in Southeast Asia, such as BajuKurung and Mini Telekung for religious costumes and contemporary Muslim women's hooded trends (Indrastomo 2016:63-64). Thoughts about the idea of the Islamic economic system and the growing trend of Islamic identity, especially in the middle class, its can't bring Islamic financial institutions in Indonesia.

The New Order's political situation in relation to Islam was very tense (antagonistic), in which power was still suspicious of the symbolization of Islam, and imposed on the single principle of Pancasila The biggest influence of the new Islamic banking policy began in 1991, when Bank Rakyat Rakyat (BPR) of Dana Mardhatillah and BPR BerkahAmal Sejahtera was initiated by Institute for Islamic Economic Development (ISED) Bandung (Ascarya and Yumanita, 2005:44). Institutional References that facilitate the establishment of the first Islamic bank in Indonesia.

There are also movers or actors that play a major role directly against the establishment of Islamic bank in Indonesia. KarnaenPerwaatmada, A.M. Saefudin, M. Amin Aziz, M. Syafi'i Antonio, from entrepreneurs such as AdiSasono, Fadel Muhammad, FahmiIdris, and others.

Even Karnaen (2016) in releasing Islamic banking issues with the jargon of "free interetsbank", as well as guarding oneself from the Islamophobio, is supported by Dr. Ahmed Mohammed Ali Al-Madani (President of the Islamic Development Bank). Karnaen also served as Executive Director of the Islamic Development Bank (IDB) Period 1988-1990.

\section{Islamic Bank is a form of religious, economic and political integration}

Islamic banking is basically a manifestation of the way of religion through the economic field that is very different from other religious fields such as prayer, fasting, and hajj. While the Islamic economic field requires openness (inclusiveness), rationality, and modern aspects in the transaction.

In both cases (religion and economy) if it has been achieved, then in realizing the empirical and juridical aspects (legality as an economic law) required another aspect of political power. This basic framework, historically existed during the founding of the first Islamic bank and its various regulatory aspects in 1992.

Indications of Islamic bank is an effort to manifest the way of religion seen in the process of establishment of the first Islamic bank in Indonesia in 1992 which can't be separated from the intellectual thinking of Indonesian Muslims, the main issue that develops about the idea of establishing Islamic banks as not-ribawi bank by Muhammadiyah and NahdlatulUlama, the two largest Islamic social organizations in Indonesia (Antonio, 1996:12).

Ali (2004:12) describes Muhammadiyah and NahdlatulUlama had long been in economic activity long before the birth of the New Order in 1965, but until the 1980s, the political role of Muslims marginalized. In the late 1980s, the New Order government began to be criticized for not involving indigenous entrepreneurs in the development process and more allowing specific rights for the Chinese minority. Muslim social forces against political power began to develop in the 1990s, at the start of a widespread middle class of intellectual Muslims who had great access to power. This middle-class group based on ICMI-MUI reflects the "religious, economic and political integration" in the process until the establishment of Islamic bank in Indonesia.

Such political-sociological processes are relevant as is the birth of the IDB (Islamic Development Bank) supported by the global social and political movement (OIC). And sociologically, the presence of the IDB is the influence of the movement of revivalism, modernism, and neo-revivalism.

On the political side, the birth of the first Islamic bank in Indonesia, as well as the impact of Soeharto's political comfort amidst the vortex of the Islamic community (ICMI-MUI) so as to encourage the government to intervene in the economic market without attacking from the opposition currents. In the theory of Islamic political economy, such government intervention according to as-Sadr (1981:721), is called al-tadâkhul al-daulah.

National political developments conducive to the breadth of Islamic symbolization, then parallel with the possibility of establishing an Islamic bank. The stronger the position of political Islam is the greater chance of establishing an Islamic bank or the development of an Islamic economic system. Conversely, the weaker the political position of Islam, the less chance of establishing an Islamic bank or building an Islamic economic system. This thesis is a strengthening of FilizBaskan (in Henry and Wilson (ed.), 2004) who conducted research in Turkey, parallel political conditions with the growth of Islamic financial institutions. 
Thus, the presence of Islamic banks in Indonesia is an important part in the realization of the integration of religious economy, and politics. Where is the bank as aeconomyactivity(al-dunyâ) but also institution in carrying out religious activities (al-dinn) through the contracts contained in the products of Islamic banks, and its existence is supported by a political power (al-daulah). This is very visible, in the event of political power (government), public (MUI), and entrepreneurs with an Islamic background led by ICMI to establish the first Islamic bank in Indonesia.

Integration al-dîn and al-daulah embodied in policy PP. 70, 71, and 72 Year 1992. But in the development from 1992 to 1998an, Muslim entrepreneurs have not responded to the Islamic banking system, as owner or customer.

The condition is very different with the establishment of Bank Malaysia Berhad (BIMB). The success of BIMB (1983) as a full-fledged commercial bank has social and economic roots that have taken place since 1963 through Tabung Haji led by The Muslim Pilgrims Saving Corporation. The success of the Tabung Haji provides a great boost to the establishment of Bank Islam Malaysia Berhad(BIMB), a fully-fledged Islamic commercial bank. The Tabung Haji contributes to 12.5 percent of BIMB's initial capital of M \$ 80 million (Ariff, 1988:47). Historical records of the pilgrimage Tabung Haji, the existence of the Malaysian political space for the earth of men or Malay (Islam), and the state's response to the establishment of an Islamic bank have created Malaysia as a world reference country in the model and development of Islamic banks.

While the establishment process of first Islamic bankin Indonesia does not have embryo based Islamic financial institution as Tabung Haji in Malaysia. Prior to 1992, several BPRS had been established, but the existence of BPRS was not directly related to the establishment of BMI, especially from the capital aspect.

Of several parties directly involved in the initial capital of the BMI reflects the very dominant existence of Suharto (al-daulah) in exercising his power to influence his subordinates; such as ministers, foundations are initiated by him, even there are SOE companies that are not related to Islam ie PT. PAL, and PT. Pindad.

The result of interview with Kara (2005) explains that Soeharto's dominance is a series of lobbying conducted by Preparation Team for establishment of Islamic bank from MUI.

According to Karnaen (2016, interview) politically formed 2 Lobby Team to prospect Suharto about Islamic bank, first through ministers, and second through Suharto's son and daughter. Even JB. Soemarlin who in fact is a nonMuslim minister also participated in the lobby and respect for the idea of establishing an Islamic bank. While directly playing the lobby team and arranging the MUI Team meeting schedule with Soeharto is the Secretary of State Minister Moerdiono. One point emphasized by Moerdiono is not to be impressed that the idea of establishing an Islamic bank or bank with the principle of profit sharing is an idea that is in line with the NII (Islamic State of Indonesia) or wishes to revive the Presidential Decree.

Described by Syafi'i Antonio (2016, interview), before facing Soeharto there are various bank names discussed by the MUI Team for preparations presented to President Soeharto, such as the name of Bank Islamic Indonesia, Bank MuamalatIslamic Indonesia, and others. Then agreed on the name of Bank Muamalat Indonesia, or Bank Muamalat Islam Indonesia

The meeting also took place on Wednesday, at $10.00 \mathrm{am}$. Perwaatamadja (2016, interview) who accompanied Hasan Basri (Chairman of the MUI at that time) to face President Soeharto explained:

Before facing Soeharto, MUI Team has brought two names namely Bank Mualamat Islam Indonesia and Bank Muamalat Indonesia. When the two names were presented to Soeharto, Soeharto chose Bank Muamalat Indonesia (BMI), with no further comment.

The result of interview with Karnaen author is different from that written by Basir (2009:26) refers to Triyuwono (2000:116), professor of accounting Universitas Brawijaya, East Java. Whereas according to Hasan Basri in the context of Suharto's political policy to "eliminate" the word Islam in the name of the bank (proposed by Bank Mualamat Indonesia/BMII) because muamalat already shows Islam and to keep the unity of the nation, and does not invite moyo (Java, disease), therefore the president does not want the establishment of the bank by using the word Islam is afraid of causing a commotion in the community.

According to Karnaen (2016), in the meeting there is no further opinion from Soeharto after agreeing on the name of Bank Muamalat Indonesia. In this period, the central figure of the supra-political structure because as part of the power, but also as part of political infrastructure because the founding actors of ICMI, BJ. Habibie.

Clement W. Henry (2015) argues that the presence of the first Islamic bank in 1992 was a major role. Bacharuddin Jusuf Habibie. He is a capital driver by mobilizing his 87 best friend as shareholder. But I found the 
other actor,KarnaenPerwaatmadja who really have a big role in designing meetings between political structures and infrastructure, even in lobbying the parliament to realize the Islamic banking system in Indonesia, and he was experience in international bank institution (IDB). This opinion is also rarely written by many researchers.

Before the issuance of Law no. 7 of 1992, there have been many other regulations that lead to the loosening of the opening of national private banks. In the period of deregulation, the author disagrees with Kara's analysis which explains, the potential of Islamic banking establishment can actually be implemented during the deregulation period, or in the pre-law era. 7 of 1992.

According to Kara (2005), the deregulation package of banking June 1, 1983 became the basis for banks to determine the interest rate in accordance with the condition of each bank, between one bank with another bank will be different in determining the interest rate. The government expects the national banks to be more aggressive in attracting the public to invest their funds in banks by determining the interest that attracts the attention of potential customers.

On the other hand, the banking deregulation policy of June 1983, could become the basis for the banking world to apply the $0 \%$ interest rate. Banks can conduct economic transactions without applying a system of interest that in the view of Islamic economics is not justified (Kara, 2005: 104-105, 130, Perwaatmadja, 1996: 32. Basir, 2009: 30-31.).

Kara's analysis, which refers to Perwaatmadja's opinion, may be appropriate that the June 1, 1983 policy allows banks to enforce transactions at $0 \%$ interest rates. However, looking at the purpose of the policy then the analysis is less precise. Because the direction of government policy is to expect high interest rates so that people become interested in saving money and deposits. Not the other way around, when the sluggishness of the people investing in the bank instead of the dinolkan interest rate that can impact savings transactions or deposits become increasingly not increased.

In the aforementioned intention, Perwaatmadja (2016) explains that the uncertain interest conditions and the government can not control where there are government-imposed interest and interest in the market, and the government can not control the market interest, the government takes a policy on interest submitted to the respective bank. In this position is already providing opportunities for the establishment of banks with noninterest system. Despite the fact, politically it is very unlikely.

The birth and regulation of Islamic bankingsupported by political aspects, MUI and other elements is a very special religious phenomenon in the New Order era. It is very difficult to do on other aspects.

The form of Islamic teachings present in the domain of economic transactions formalized in government regulations (PP No. 70, 71, and 72 of 1992) can be regarded as an omnipresence Islam, using BahtiarEffendy, Islam which is present everywhere and provides "moral guidance which is true for human action "(Effendy, 1998: 6-8, Binder, 1988: 4).

The subject that embodies the policy is a political and religious collaboration in economics as a matter of which FazlurRahman is a compact totality in offering solutions to life's problems (Rahman, 1996: 241, Effendy, 1998:7).

\section{Conclusion and recommendation}

The harmonious politic between state and Islam in the New Orde found the best situation when there was a shift in the government's view of the relational policy between power and the movement and thinking of Muslims in the 1990s.

At the first Islamic bank was born in 1992, there was "accommodative politics" or harmonization of relation of superstructure (ruler) and Moslem. However, if the presence of Islamic bank is only related to "accommodative politics" then it is less appropriate in the framework of political economy study. Because the nature of the policy in "accommodative politics" is top-down, the government is taking the initiative to accommodate the Muslims interests in structural positions.

So in "accommodative politics" policy products in the sense of regulation or regulation is not explicit. The policy is implicit in that there is a change of power policy but not accompanied by a certain regulatory change. Like when the president appointed ministers from ICMI and Muslims who are almost 80\%, parliamentwho is also a lot of Muslims or santri and raises the term "ijoroyo-royo", it as a phenomenon and implicit only. Because the President does not change the explicit policy of free political Islam open to the public. 
In the analysis of political economy, the writer sees the presence of the first Islamic bank in Indonesia is a success of Islamic political infrastructure/interest group (ICMI, MUI, LSAF, mainly through B.J. Habibie) that influence political power/superstructure to create policy in Islamic bank establishment process.

So an important point in political economy is bottom-up by interest-group. The power (political superstructure) is not merely an accommodation of interest-group/bottom-up thinking, but power creates an explicit policy product that is a series of policy packages. 70, 71, and 72 of 1992 which marked the legality of the establishment of banks and BPR with the principle of profit sharing. The three PPs reinforce legislation No. 7/1992 concerning Banking which was previously issued and became the basis for establishing a bank with the principle of profit sharing. Some of these policy products can then give birth to 1 Islamic bank and 70s BPRS until the end of New Order's power in 1998an.

With the success of the political infrastructure of Islam in the field of economy in realizing the formal institution of Islam in banking, and the emergence of regulation that strengthens it politically, shows the movement of Islamic economics is a "synthesis" of Islamic awakening through political process. Where in earlier times, the state thesis tended to be "antithesis" with the mission of Islamic awakening in Indonesia.

On the other hand, although the 1990s, the political superstructure has largely accommodated Muslim thought in practical areas for inclusion of executive or legislative powers, but government policy remains consistent "No Political Islam", or no room for Islamic political parties.

Under these contrasting conditions, the presence of a political superstructure policy on the "principle bank of results" and the birth of Islamic banks and Islamic rural banks is an "anomaly" of politics. As the government maintains a "substantive Islam" in practical political dimensions, but on the territory of the economic system, governments make different policies in "formalistic Islam" by legalizing bank regulation and institutions with "profit-sharing" frills.

The anomaly of the New Order's policy of understanding the formalistic Islam between the economic system and the political system. I think the group of ICMI-MUI (plus the existence of the LSAF, PPA) are the most influential actors of the New Order policy change.

The recommendation of this study is that the affiliated political superstructure should be bold enough to push policies that lead to the development of more economically and socially Islamic banking as in Malaysia.

Indonesia is very large in the population of Muslims and geographic so it is worthy to become a reference of Islamic banking in particular and Islamic financial institutions in general.***

\section{References}

Abdul AzizThaba (1996). Islam dan Negara dalam Politik Orde Baru, Jakarta: Gema Insani Press.

Abrar Muhammad (ed.). (1991). ICMI dan Harapan Umat, Jakarta: Yayasan Pendidikan Islam Ruhama.

Ahmad Erani Yustika. (2009). Ekonomi Politik: Kajian Teoritis dan Analisis Empiris Yogyakarta: Pustaka Pelajar.

Ahmad Syafi'i Ma'arif. (1995a). Membumikan Islam, Yogyakarta: Pustaka Pelajar. . (1995b). Peta Bumi Intelektualisme Islam di Indonesia, Bandung: Mizan, Dzulqa'dah.

Ahmed Belouafi dan Abdelkader Chachi. (2004). "Islamic Finance in the United Kingdom: Factors Behind its Development and Growth", Jurnal Islamic Economic Studies, IRTI, Volume. 22, No. 1, Mei.

Ali Fauzi (ed.). (1995). ICMI Antara Status Quo dan Demokratisasi, Bandung: Mizan.

Ascarya dan Diana Yumanita. (2005). Bank Islamic: Gambaran Umum, Seri Ke-14, Jakarta: Pusat Pendidikan Dan Studi Kebanksentralan (PPSK).

Bahtiar Effendy. (1998). Islam dan Negara, Transformasi Gagasan dan Praktik Politik Islam di Indonesia, terj.: Ihsan Ali Fauzi dan Rudi Harisyah Alam, Jakarta: Paramadina.

Banjaran Surya Indrastomo. (2016). "The Emergence of Islamic Economic Movement in Indonesia: A Political Economy Approach", dalam Kyoto Bulletin of Islamic Area Studies, 9 Maret.

Chandra Ismail, dkk. (2013). Bank Syari'ah Setelah Dua Dekade, Pemikiran dan Biografi Karnaen Anwar Perwaarmadja, Jakarta: Duta Pustaka Indonesia.

Christofer Engzell. (2008). "Islamic Banks in the United Kingdom: Growth in the 21st century", 4-5 Juni, 2008, Uppsala University, Department of Economic History (online), http://www.diva-portal.org.

Cik Basir. (2009). Penyelesaian Sengketa Perbankan Islamic, Jakarta: Prenada.

Clement M. Henry dan Rodney Wilson (ed.). (2004). The Politics of Islamic Finance, Edinburgh: Edinburgh University Press. 
Clement W. Henry. (2015). "Islamic Finance in Indonesia: High Tide or New Mecca?", dalam Jurnal MEI Perspectives, Middle East Institute, National University of Singapore, Series 5, tanggal 10 Agustus 2015.

Diro Aritorang. (1990). “Institusi Membuat Cendekiawan Muslim Steril?”, Pikiran Rakyat, 21 Desember.

Fazlur Rahman. (1996). Islam, New York, Chicago, San Fransisco: Holt, Winston.

Iwan Triyowono. (2000). Organisasi dan Akuntansi Syari’ah, Yogyakarta: LKiS.

James A. Caporasodan David P. Levine. (2008). Teori-teori Ekonomi Politik, Terj. Suraji, Yogyakarta: Pustaka Pelajar. Judith Goldstein. (1993). Ideas, Interest and American Trade Policy, Ithaca and London: Cornell University Press.

Kamaruzzaman Bustamam Ahmad. (2004). Wajah Baru Islam di Indonesia, Yogyakarta: UII Press.

Karnaen A. Perwaatmadja. (1996). Membumikan Ekonomi Islam di Indonesia, Depok: Usaha Kami. . (2016). Wawancara, Selasa, tanggal 12 Juli 2016, di Kediaman Beliau, Komplek Perumahan Moneter CC-3, Jakarta.

Kompas.com (online). (2008). "Rumah Harta untuk Semua", Bisnis \& Keuangan, tanggal 26 November, http://ekonomi.kompas.com.

Leonard Binder. (1998). Islamic Liberalism: A Critique of Development Ideologies, Chicago, London: University of Chicago Press.

M. Dawam Rahardjo. (1990). Etika Ekonomi dan Manajemen, (Yogyakarta: Tiara Wacana. (1991). "Ensiklopedi Riba", dalam Jurnal Ulumul Qur'an, Jakarta: LSAF. (1996). Intelektual, Intelegensia dan Perilaku Politik Bangsa, Bandung: Mizan.

M. Syafi'i Antonio. (2001). Bank Islamic, Dari Teori Ke Praktek, Jakarta: Gema Insani Press. . (2016). Wawancara pada Rabu, tanggal 13 Juli 2016, di Masjid Andalusia, Komplek Tazkia Institute, Sentul City, Cibinong Bogor.

M. Syafi'i Anwar. (1995). Pemikiran dan Aksi Islam Indonesia: Sebuah Kajian Politik Tentang Cendekiawan Orde Baru, Jakarta: Paramadina.

Mervyn K. Lewis danLatifa M. Algaoud. (2001). Islamic Banking, UK, USA: Edward Elgar.

Mohamed Ariff. (1988). "Islamic Banking”, Jurnal Asian-Pacific Economic Literature, Vol. 2, No. 2, September.

Muhamad Ali. (2004). "Islam and Economic Development in New Order's Indonesia (1967-1998)", Makalah dipresentasikan pada the 3rd East-West Center International Graduate Student Conference, di Honolulu, Hawaii, Amerika Serikat, tanggal 19-21 Februari 2004. Dipublikasikan dalam International Graduate Conference Series/East-West Center Paper Series, Nomor 12, Tahun 2004.

Muhammad Baqr al-Sadr. (1981). Iqtishaduna, Beirut: Dar al-Ta'aruf Lilmathbu'at, 1981.

Muslimin H. Kara. (2005). Bank Islamic di Indonesia, Yogyakarta: UII Press.

Mutiara Dwi Sari, Zakaria Bahari, Zahri Hamat. (2016). "History of Islamic Bank in Indonesia: Issues Behind Its Establishment", dalam International Journal of Finance and Banking Research, Volume 2, Nomor 5.

Nasrullah Ali Fauzi (ed.). (1995). ICMI Antara Status Quo dan Demokratisasi, Bandung: Mizan.

Nazih N. Ayubi. (1991). Political Islam; Religion and Politics in The Arab World, London and New York: Routledge.

Okeke V.O.Sdan Ojukwu Uche Grace. (2012). "The Political Economy of The Proposed Islamic Banking and Finance in Nigeria: Prospects and Challenges", dalam Kuwait Chapter of Arabian Journal of Business and Management Review, Volume 1, Nomor 7, Maret.

Richard Robison. (1990). Power and Economy in Soeharto's Indonesia, Manila dan Wolongong: Journal Contemporary Asia Publisers.

Richard Robison. (1996). Indonesia-The Rise of Capital, Sidney: Allen and Unwin.

Rizal Mallarangeng. (2002). Mendobrak Sentralisme Ekonomi: Indonesia 1986-1992, terj. Martin Aleida, Jakarta: Gramedia.

Robert W. Hefner. (2001). "Public Islam and the Problem of Democratization", dalam Sociology of Religion, Published by Oxford University Press, Volume 62, Nomor 4.

Rodney Wilson. (2007). "Islamic Finance in Europe", RSCAS Policy Papers, European University Institute, NO. 02. http://www.eui.eu.

Shofwan al-Banna Choiruzzad dan Bhakti Eko Nugroho. (2013). "Indonesia's Islamic Economy Project and the Islamic Scholars", dalam N. Agya Utama (ed.), Procedia Enviromental Science, Volume 17, Tahun 2013, The 3rd International Conference on Sustainable Future for Human Security, SUSTAIN 2012, 3-5 November 2012, Kyoto University, JAPAN.

Sujono dan Abdurrahman. (1998). Metodologi Penelitian, Suatu Pemikiran dan Penerapan, Jakarta: Rineka Cipta.

Vedi R. Hadiz. (2011). "Indonesian Political Islam: Capitalist Development and the Legacies of the Cold War", dalam Journal of Current Southeast Asian Affairs, 30, No. 1. 